\title{
Development of Edible Biofilm Containing Cinnamon to Control Food-Borne Pathogen
}

\author{
Deepansh Sharma*, Daljeet Singh Dhanjal, Bhumika Mittal \\ School of Bioengineering and Biosciences, Lovely Professional University, Phagwara, Punjab, India.
}

\begin{tabular}{l} 
ARTICLE INFO \\
\hline Article history: \\
Received on: $29 / 07 / 2016$ \\
Revised on: 19/09/2016 \\
Accepted on: 23/11/2016 \\
Available online: $31 / 01 / 2017$ \\
\hline Key words: \\
Cinnamon, Biodegradable \\
edible films, Food packaging, \\
Preservation, Antimicrobial \\
activity.
\end{tabular}

\section{INTRODUCTION}

In current scenario, the biofilms or coatings have gained approval for the storage of foods, beverages, and medicines because of its ability to decrease pollution exerted by the commercial products made up of the polymers and are nonbiodegradable (Malathi et al., 2014). The additional benefits provide by the biofilms or coatings are related to the reduced cost and their ability to control moisture gases and lipid migration and also aids during the addition of additives and nutrients. Nowadays, the different polymers are used for synthesizing the edible films such polysaccharides, proteins and lipids or blend of either two of the polymers (Capitani et al., 2016). Edible films synthesized are envisioned to elevate the mean life and lessen the chance of attack by the contaminants (McHugh et al., 1994). Although many researches documented about distinct essential oils such as cinnamon and clove like fennel, cypress, lavender, thyme, herbs of cross pine and rosemary shows antimicrobial

\footnotetext{
* Corresponding Author

Deepansh Sharma, School of Bioengineering and Biosciences,

Lovely Professional University, Phagwara, Punjab, India.

Email: deepanshsharma @ gmail.com
}

activity against certain types of bacteria which can be employed to prevent the food spoilage. The reports have been cited showing the antiviral, anti-toxigenic, anti-parasitic and insecticidal properties of these essential oils. The food industry has got highly interested with the idea of packaging material with antimicrobial activity, as the demand of consumer increases for the food product free from preservatives.

The use of polysaccharide such as pectin for the synthesis of biofilm provides the properties such as water solvency and reduced water permeability (Xu et al., 2005). On the other hand, whey protein shows properties like gas and mechanical barrier as compared to biofilms synthesized from polysaccharides. The molecular structure of whey protein displays high intermolecular binding potential (Jolie et al., 2010). Biofilms, which are synthesized from these biopolymers are delicate and less manipulative by mechanical means. Thus, it has become essential to use the plasticizer to increase the flexibility and extensibility and additives are also added which facilitates as cross-linking agent. Whereas the excess amount of additives results in declination of flexibility, porosity, and permeability to gases, water vapours and solvents (Flores et al., 2010). 
Nowadays, the awareness has been observed from consumer aspect, preferring healthy food provides health benefits. Thus, on this basis pectin and whey protein integrated with cinnamon products like cinnamic acid, cinnamon essential oil and cinnamon powder are utilized for synthesizing the edible biofilms. These edible biofilms on packaging interacts with the product as well as environment to increase adaptation phase whereas decline the proliferation rate of microbes. Currently, different plant essential oils are being extracted and integrated with biofilm components for evaluating their antimicrobial activity.

However, very less information is available about the plant essential oil as antimicrobial agents which can be used in combination for producing edible biofilms and coating. Main objective to conduct this study was to fabricate and characterized biofilm made from the edible source containing cinnamon as antimicrobial agent.

\section{MATERIALS AND METHODS}

\section{Materials}

Cinnamon powder (CP), Cinnamon essential oil (CEO) were attain from local market. Cinnamic acid (CA), pectin, glycerol and Tween 20 used in present study were of analytical grade. The bacterial strain of Escherichia coli and Staphylococcus aureus were used for determination of antibacterial activity were previously isolated from the market food samples.

\section{Film Preparation}

Whey protein of $8 \% \quad \mathrm{w} / \mathrm{v}$ and Pectin $1 \% \quad \mathrm{w} / \mathrm{v}$ concentration was used to formulate the edible films as follows; whey protein powder and pectin plus gelatin mixed and $\mathrm{pH}$ was adjusted to 8.0, after which it was heat at $90 \mathrm{oC}$ for $30 \mathrm{~min}$ in a water bath. After that glycerol was added in 1:1 ratio. Later, Tween 20, at a level of $0.2 \% \mathrm{v} / \mathrm{v}$, was added as an emulsifier to help dissolution in the film-forming solution. After $30 \mathrm{~min}$ of stirring, essential oils at $1 \%, 2 \%, 3 \%$ and $4 \% \mathrm{v} / \mathrm{v}$ concentration was added to the film-forming product. The solution was kept at room temperature for $30 \mathrm{~min}$ using a magnetic bead stirrer.

Five grams of the solutions was casted on $90 \mathrm{~mm}$ glass petri plates then dried for $72 \mathrm{~h}$ at $37{ }^{\circ} \mathrm{C}$. Dried films were peeled from the plates and stored in a chamber at ambient temperature (Seydim and Sarikus, 2006).

\section{Antibacterial Potential}

To examine the antibacterial potential of with $\mathrm{CP}, \mathrm{CA}$, CEO and cinnamon powder, the pectin and whey protein film integrated $\mathrm{CP}, \mathrm{CA}, \mathrm{CEO}$, by utilizing the agar diffusion technique. Inoculum of $E$. Coli, L. monocytogenes and $S$. aureus were inoculated separately and cultured it for overnight. Petri dishes with Muller Hilton agar were inoculated with the bacterial suspension with cotton swab. The five wells were made on the agar plate and $30 \mu 1$ solution by which film is to be formed was added into wells and incubated at $37{ }^{\circ} \mathrm{C}$. Antibacterial potential was calculated by determining the inhibition zone

\section{Characterization of the Films \\ Film Thickness}

Thickness of whey and pectin films were estimated with the help of a digital micro meter of resolution $0.01 \mathrm{~mm}$ on ten different positions. The mean value of the thickness was determined by the average of the thickness at different position $\mathrm{Du}$ et al. (2009).

\section{Moisture Content}

For estimating the moisture content, reduction in the mass of the films is observed when it is exposed to the $100^{\circ} \mathrm{C}$. The net variation between initial and final moisture content of the film provide statistics about the moisture content, according to the formula used by Soltani et al. (2014).

Moisture Content $(\%)=($ I.M - F.M $) * 100 /$ I.M

Here, I. M = Initial Moisture and F. M = Final Moisture

\section{Transparency determination}

The transparency of the film was estimated with UV-Vis Spectrophotometer (Systronics Double Beam). The film was cut into long rectangular shapes (dimensions) and put in quartz cuvette, and absorbance was measured at the wavelength of $550 \mathrm{~nm}$. According to Han et al. (1997) transparency (T) can be evaluated with formula:

$\mathrm{T}=A_{550} /$ film thickness

Here, $A=$ absorbance of the film at a wavelength of $550 \mathrm{~nm}$.

\section{Fourier Transform Infrared Spectroscopy}

For evaluating the interaction among the functional groups of pectin as well as whey protein with cinnamon oil was done with the use of Fourier Transform Infrared (FTIR) Spectroscopy at room temperature in scanning range of 500-4000 $\mathrm{cm}^{-1}$ (Pranoto et al., 2005).

\section{RESULTS AND DISCUSSION}

\section{Antibacterial Potential of different cinnamon variations}

The antibacterial Potential was analysed for $\mathrm{CP}, \mathrm{CA}$ and CEO. The maximum zone of inhibition was observed for the CEO of $5 \%(\mathrm{v} / \mathrm{v})$ concentration as compared to the $\mathrm{CP}$ and CA. The CEO showed effective inhibition zone against the E. coli, $S$. aureus and L. monocytogenes at $5 \%(\mathrm{v} / \mathrm{v})$ essential oil. Thus this minute volume of CEO exhibited the effective result were used for further analysis. For further assessment the CEO was integrated with the pectin and whey film. CEO was reported for significant antibacterial potential against pathogens. Bahram et al. (2014) reported CEO for their antimicrobial activities against various food contaminants like B. subtilis, L. monocytogenes, E. coli and Candida albicans at $1.5 \%(\mathrm{v} / \mathrm{v})$ concentration. Whey protein integrated with CEO which act as antibacterial compound while preparing the edible film. Films containing CEO displayed prominent antibacterial potential against food pathogens, and showed significant inhibitory outcome with Candida albicans. Antimicrobial activities of Cinnamon Oil and 
Cinnamaldehyde showed significant inhibition of $S$. aureus, E. coli, E. aerogenes, $P$. vulgaris, $P$. aeruginosa, $V$. cholerae, $V$. parahaemolyticus and $S$. typhymurium, $C$. albicans and Aspergillus spp. (Ooi et al., 2006). In present study, antimicrobial activities of $\mathrm{CA}$ and $\mathrm{CP}$ displayed poor antibacterial potential as correlated with CEO.

Table-1: Antimicrobial activity of the Cinnamon powder (CP), Cinnamic acid (CA) and Cinnamon essential oil (CEO) against food borne pathogens.

\begin{tabular}{|c|c|c|c|c|}
\hline \multirow[b]{2}{*}{$\begin{array}{c}\text { Film Forming } \\
\text { Solution }\end{array}$} & \multirow[b]{2}{*}{ 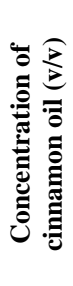 } & \multicolumn{3}{|c|}{ Zone of Inhibition (mm) } \\
\hline & & 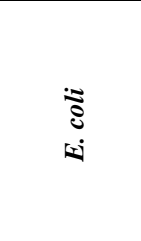 & 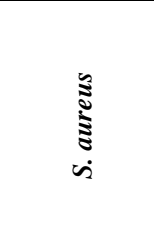 & 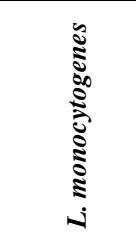 \\
\hline \multirow{4}{*}{$\begin{array}{l}\text { Cinnamic powder } \\
(\mathrm{CP})\end{array}$} & $1 \%$ & $6.85 \pm 0.2$ & $6.27 \pm 0.23$ & $5.53 \pm 0.11$ \\
\hline & $2 \%$ & $7.13 \pm 0.12$ & $7.25 \pm 0.11$ & $6.21 \pm 0.12$ \\
\hline & $3 \%$ & $7.95 \pm 0.22$ & $8.00 \pm 0.19$ & $7.23 \pm 0.12$ \\
\hline & $4 \%$ & $8.39 \pm 0.15$ & $8.45 \pm 0.16$ & $7.45 \pm 0.19$ \\
\hline \multirow{4}{*}{$\begin{array}{c}\text { Cinnamic acid } \\
\text { (CA) }\end{array}$} & $1 \%$ & $9.85 \pm 0.17$ & $8.03 \pm 0.15$ & $3.56 \pm 0.15$ \\
\hline & $2 \%$ & $10.31 \pm 0.23$ & $8.70 \pm 0.12$ & $4.27 \pm 0.14$ \\
\hline & $3 \%$ & $10.52 \pm 0.11$ & $9.08 \pm 0.10$ & $4.23 \pm 0.16$ \\
\hline & $4 \%$ & $10.68 \pm 0.14$ & $10.14 \pm 0.29$ & $6.48 \pm 0.19$ \\
\hline \multirow{3}{*}{$\begin{array}{c}\text { Cinnamon } \\
\text { essential oil (CEO }\end{array}$} & $1 \%$ & $13.07 \pm 0.15$ & $11.505 \pm 0.22$ & $10.73 \pm 0.23$ \\
\hline & $2 \%$ & $16.31 \pm 0.19$ & $16.195 \pm 0.21$ & $13.54 \pm 0.21$ \\
\hline & $3 \%$ & $17.52 \pm 0.22$ & $16.330 \pm 0.10$ & $17.81 \pm 0.24$ \\
\hline
\end{tabular}

\section{Antibacterial Potential of Pectin and whey films integrated with CEO}

Antibacterial potential of edible films disks are presented in Table 2. No antibacterial activity was visualized on the control film disks which doesn't contains CEO against tested pathogens, which resemble with outcome attained by Bahram et al. (2014) with edible films formed from whey protein. Edible films of whey as well as pectin integrated with CEO showed significant inhibition against tested pathogens. Accumulation of CEO into whey and pectin resulted in dispersion of antibacterial essential oil by employing Mueller Hinton agar medium plates and delivered an inhibition zone adjacent the film disks for all the pathogens tested.

Various reports informed that CEO could suppress the proliferation of pathogenic microorganisms (Ouattara et al. 2000; Matan et al., 2012; Valero and Salmeron 2003, Ojagh et al. 2010). The minimum zone of inhibition was observed for $E$. coli in edible film disks (15.55 and $11.66 \mathrm{~mm}$ for pectin and whey film disks respectively).

The maximal activity was observed for $S$. aureus and $L$. monocytogenes $(26.39,26.88$ and $13.78,14.56 \mathrm{~mm}$ respectively for edible films of pectin and whey comprising $5 \%(\mathrm{v} / \mathrm{v})$ essential oil. Inhibition zone developed by edible disks were maximal in comparison to the edible disk, probably because of more dispersion of essential oils through the film wells in relation to pectin and whey edible film disks. Reports have been documented that antimicrobial activities were more effective against the gram positive bacteria as compared to the Gram negative bacteria (Sanchez-González et al., 2011).

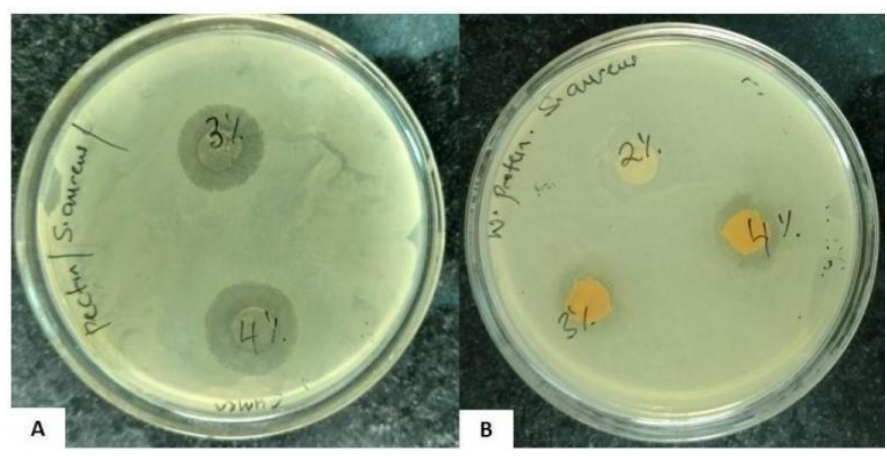

Fig. 1: Antimicrobial activity of the edible packaging films

Table-2: Antibacterial potential of the edible film of pectin and whey containing Cinnamon essential oil against food borne pathogens.

\begin{tabular}{lllll}
\hline & & \multicolumn{3}{c}{ Zone of Inhibition $(\mathbf{m m})$} \\
\cline { 3 - 5 } & & & & \\
\hline Pectin film & $5 \%$ & $15.55 \pm 0.12$ & $26.39 \pm 0.23$ & $26.88 \pm 0.10$ \\
Whey film & $5 \%$ & $11.60 \pm 0.10$ & $13.78 \pm 0.21$ & $14.56 \pm 0.13$ \\
\hline
\end{tabular}

\section{Characterization of the Films Film thickness}

The biofilms synthesized from the pectin, whey protein blended with CEO were measured at 10 different positions with the digital micro meter $(0.001 \mathrm{~mm})$ to estimate the thickness of the biofilms (figure-1). Thus for estimating the physical as well as mechanical traits the arithmetic mean is employed. The thickness based on the weigh (in gm.) is represented in the table 3. The thickness of the pectin and whey edible films were increased with increased in amount of film forming solutions ranges from 0.1240.249 and $0.136-0.200$ respectively. The thickness of pectin and whey edible films did not exhibit any alteration on integration of CEO, but were in range of 0.125 to 0.127 and 0.127 to $0.247 \mathrm{~mm}$ respectively as represented in Table 3 . Strengthening edible films of pectin and whey could be associated with the change in the microstructure during the interaction among the film and essential oil and which also grant something to mean thickness of the film. Bahram et al. (2014) also reported the similar results while incorporated CEO in whey protein edible films and observed that there was no significant transition in the thickness due to the integration of $\mathrm{CEO}$ ranging from 0.31 to $0.34 \mathrm{~mm}$. The incorporation of essential oil did not change the thickness of the edible film considerably also the amount of essential oil incorporated attributed to the tensile strength of the edible film. Similar results were encountered in the antibacterial potential and physical traits of edible films integrated with polyphenols from the apple skin (Du et al., 2011). The integration of polyphenols of 
apple skin contributes for strengthening of the edible films and associated with the cooperation among apple film and skin polyphenols. The thickness of apple edible films is directly proportional to polyphenols concentration.

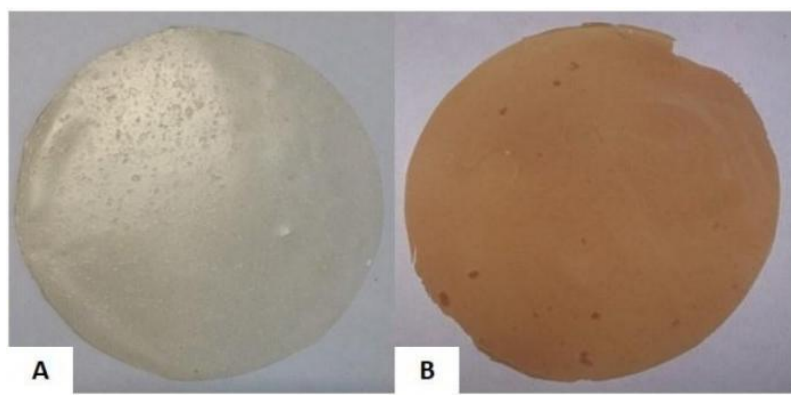

Fig. 2: Representation of edible films incorporating cinnamon essential oil (A) Pectin edible film (B) Whey protein edible film.

Table 3: Representation of thickness (in $\mathrm{mm}$ ) with respect to weight of the biofilm

\begin{tabular}{ccc}
\hline Films & Weigh $(\mathbf{g m})$ & $\begin{array}{c}\text { Thickness } \\
(\mathbf{m m})\end{array}$ \\
\hline \multirow{2}{*}{ Pectin } & 2.5 & $0.124 \pm 0.03$ \\
& 3.0 & $0.149 \pm 0.02$ \\
Whey Protein & 4.0 & $0.249 \pm 0.05$ \\
\hline \multirow{2}{*}{ Pectin + Cinnamon essential oil } & 3.0 & $0.136 \pm 0.04$ \\
& 4.0 & $0.200 \pm 0.02$ \\
\hline \multirow{2}{*}{ Whey + Cinnamon essential oil } & 2.5 & $0.125 \pm 0.02$ \\
& 3.0 & $0.151 \pm 0.05$ \\
& 4.0 & $0.253 \pm 0.02$ \\
\hline
\end{tabular}

\section{Moisture Content}

Moisture content was calculated to determine the water affinity of the biofilm. The result displays that the PCO $(4.69 \%)$ and WCO $(5.75 \%)$ has less moisture content as compared to control pectin $(6.34 \%)$ and whey protein edible films $(8.45 \%)$. The moisture content values of PCO and WCO edible films considerably reduced as it is integrated with CEO. That is further associated with hydrophobic traits of cinnamon oil. Packaging edible films have to sustain moisture content within the wrapped food product. For that reason, the assessment of edible films moisture content is important until active food packaging is concerned. Comparative analysis of the data was done on the emulsified fatty acid edible films as well as the protein pistachio

Decline in moisture content in protein-olive oil possibly be associated with protein-water exchange mechanism commenced in the emulsified films (Zahedi et al., 2010; Rocca-Smith et al., 2016).

Table 4: Moisture content determination of pectin and whey edible films.

\begin{tabular}{lc} 
Table 4: Moisture content determination of pectin and whey edible films. \\
\hline \multicolumn{1}{c}{ Edible Film } & $\begin{array}{c}\text { Moisture } \\
\text { Content (\%) }\end{array}$ \\
\hline Pectin film without cinnamon essential oil (control) & 6.34 \\
Whey protein film without cinnamon essential oil (control) & 8.45 \\
Pectin + Cinnamon Essential oil (PCO) & 4.69 \\
Whey Protein + Cinnamon essential oil (WCO) & 5.75 \\
\hline
\end{tabular}

\section{Transparency determination}

The opaque biofilms were analysed with UV-Vis spectrophotometer at two different wavelengths $280 \mathrm{~nm}$ and 550 $\mathrm{nm}$ for transmittance and UV opacity. The incorporation of CEO revealed decline in edible film opaqueness on comparison with control film (pectin and whey), implying regarding the transparency of the packaging films as it was integrated with CEO (Table-5). In spite of this, PCO and WCO edible films, the gelatin films showed sharp decrease in UV opacity even when it is incorporated with 5\% CEO from 47.14, 48.32 to 6.46 and 6.32 respectively. Edible films transparency is the major concern while synthesizing food packaging material as it is directly correlated with the exterior of the packaged material. Transparency acts as an additional factor to exploit the constituents of edible film (Liu and Zhang, 2006). If empathy amongst edible film ingredients is not clear, thus induces hindrance in transmittance which is reduce because light gets reflected towards the two-phase interface (Rhim et al., 2007).

Table-5: Film opacity (A550/mm) values for the control films and PCO and WCO edible films.

\begin{tabular}{ccc}
\hline Edible films & $\begin{array}{c}\text { Transmittance } \\
\text { \% (550nm) }\end{array}$ & $\begin{array}{c}\text { UV } \\
\mathbf{( 2 8 0 n m )}\end{array}$ \\
\hline Pectin & 85.56 & 47.14 \\
Whey protein & 84.37 & 48.32 \\
Cinnamon essential oil + Pectin & 78.03 & 6.46 \\
Cinnamon essential oil + Whey protein & 76.76 & 6.32 \\
\hline
\end{tabular}

\section{Fourier Transform Infrared Spectroscopy}

Spectra obtained from PCO and WCO edible films showed identical arrangement of peaks of absorption in the range of 3400 and $840 \mathrm{~cm}^{-1}$. Spectral peaks within the range 3400 and $1020 \mathrm{~cm}^{-1}$ coincide with the $-\mathrm{OH}$ arrangement of functional group of hydroxyl, $(\mathrm{C}=\mathrm{O})$ bonded to aromatic group. Similar results were also reported when working on cinnamon incorporated edible films (Siripatrawan and Harte, 2010). Peak of the control as well as of the film integrated with $5 \%$ CEO illustrated the notable spectral lines at $3,232 / \mathrm{cm}$. The absorption bands perceived within 1,600 and $1,700 / \mathrm{cm}(1,627 / \mathrm{cm})$ signify the existence of amid I bands (extension of $\mathrm{C}=\mathrm{O}$ ) (Andreuccetti et al. 2009).

\section{CONCLUSIONS}

Current study was focused on the scrutinizing the pectin as well as whey protein which are incorporated with the cinnamon oil as the antibacterial agents. The antibacterial potential of cinnamon oil was notably higher than cinnamon powder as well as cinnamic acid against $E$. coli and $S$. aureus. It was observed that integration of CEO with edible film doesn't hinder the permeability of water vapour and tensile property. FTIR provide the information related to the interaction between the functional groups of antimicrobial agent with biofilm polymers. The results signify the cinnamon essential oil as the efficient antimicrobial agent against pathogenic bacteria which can be used in the packaging material. Thus, it is essential to persist with this 
research to obtain edible biofilm with improved physical and biological properties. That can be employed in the packaging industry for coating the food such as the bakery product, dairy product, meat and vegetable without affecting their quality. The edible films development can be scaled up using low cost agriculture residues for as a casting polymers, which in turns can regulate the cost of production and would be an alternative to the conventional packaging material.

\section{Financial support and sponsorship: Nil.}

Conflict of Interests: There are no conflicts of interest.

\section{REFERENCE}

Andreuccetti C, Carvalho RA, Grosso CR. Effect of hydrophobic plasticizers on functional properties of gelatin-based films. Food Research International. 2009; 42(8):1113-21.

Bahram S, Rezaei M, Soltani M, Kamali A, Ojagh SM, Abdollahi M. Whey protein concentrate edible film activated with cinnamon essential oil. Journal of Food Processing and Preservation. 2014; 38(3):1251-8.

Capitani MI, Matus-Basto A, Ruiz-Ruiz JC, Santiago-García JL, Betancur-Ancona DA, Nolasco SM, Tomás MC, Segura-Campos MR. Characterization of Biodegradable Films Based on Salvia hispanica L. Protein and Mucilage. Food and Bioprocess Technology. 2016:1-1.

Du WX, Olsen CW, Avena-Bustillos RJ, Friedman M, McHugh TH. Physical and antibacterial properties of edible films formulated with apple skin polyphenols. Journal of Food Science. 2011; 76(2):M149-55.

Du WX, Olsen CW, Avena-Bustillos RJ, McHugh TH, Levin CE, Friedman M. Effects of allspice, cinnamon, and clove bud essential oils in edible apple films on physical properties and antimicrobial activities. Journal of Food Science. 2009; 74(7):M372-8.

Flores SK, Costa D, Yamashita F, Gerschenson LN, Grossmann MV. Mixture design for evaluation of potassium sorbate and xanthan gum effect on properties of tapioca starch films obtained by extrusion. Materials Science and Engineering: C. 2010; 30(1):196-202.

Giosafatto CV, Di Pierro P, Gunning AP, Mackie A, Porta R, Mariniello L. Trehalose-containing hydrocolloid edible films prepared in the presence of transglutaminase. Biopolymers. 2014; 101(9):931-7.

Han JH, Floros JD. Casting antimicrobial packaging films and measuring their physical properties and antimicrobial activity. Journal of Plastic Film and Sheeting. 1997; 13(4):287-98.

Jolie RP, Duvetter T, Van Loey AM, Hendrickx ME. Pectin methylesterase and its proteinaceous inhibitor: a review. Carbohydrate Research. 2010; 345(18):2583-95.

Liu D, Zhang L. Structure and properties of soy protein plastics plasticized with acetamide. Macromolecular Materials and Engineering. 2006; 291(7):820-8.

Malathi AN, Santhosh KS, Nidoni U. Recent trends of biodegradable polymer: biodegradable films for food packaging and application of nanotechnology in biodegradable food packaging. Current Trends in Technology and Science. 2014; 3(2):73-9.

Matan N. Antimicrobial activity of edible film incorporated with essential oils to preserve dried fish (Decapterus maruadsi). International Food Research Journal. 2012; 19(4):1733-8.

McHugh TH, Krochta JM. Sorbitol-vs glycerol-plasticized whey protein edible films: integrated oxygen permeability and tensile property evaluation. Journal of Agricultural and Food Chemistry. 1994; 42(4):841-5.
Ojagh SM, Rezaei M, Razavi SH, Hosseini SM. Development and evaluation of a novel biodegradable film made from chitosan and cinnamon essential oil with low affinity toward water. Food Chemistry. 2010; 122(1):161-6

Ooi LS, Li Y, Kam SL, Wang H, Wong EY, Ooi VE. Antimicrobial activities of cinnamon oil and cinnamaldehyde from the Chinese medicinal herb Cinnamomum cassia Blume. The American journal of Chinese medicine. 2006; 34(03):511-22.

Ouattara B, Simard RE, Piette G, Bégin A, Holley RA. Inhibition of surface spoilage bacteria in processed meats by application of antimicrobial films prepared with chitosan. International Journal of Food Microbiology. 2000; 62(1):139-48.

Pranoto Y, Salokhe VM, Rakshit SK. Physical and antibacte rial properties of alginate-based edible film incorporated with garlic oil. Food research international. 2005; 38(3):267-72.

Rhim JW, Lee JH, Ng PK. Mechanical and barrier properties of biodegradable soy protein isolate-based films coated with polylactic acid. LWT-Food Science and Technology. 2007; 40(2):232-8.

Rocca-Smith JR, Marcuzzo E, Karbowiak T, Centa J, Giacometti M, Scapin F, Debeaufort F.. Effect of lipid incorporation on functional properties of wheat gluten based edible films. Journal of Cereal Science, 2016; 69, 275-282.

Sánchez-González L, Pastor C, Vargas M, Chiralt A, GonzálezMartínez C, Cháfer M. Effect of hydroxypropylmethylcellulose and chitosan coatings with and without bergamot essential oil on quality and safety of cold-stored grapes. Postharvest Biology and Technology. 2011; 60(1):57-63

Seydim AC, Sarikus G. Antimicrobial activity of whey protein based edible films incorporated with oregano, rosemary and garlic essential oils. Food research international. 2006; 39(5):639-44.

Siripatrawan U, Harte BR. Physical properties and antioxidant activity of an active film from chitosan incorporated with green tea extract. Food Hydrocolloids. 2010; 24(8):770-5.

Soltani M, Alimardani F. Moisture content prediction of Iranian wheat using dielectric technique. Journal of food science and technology. 2014; 51(11):3500-4.

Valero M, Salmeron MC. Antibacterial activity of 11 essential oils against Bacillus cereus in tyndallized carrot broth. International journal of food microbiology. 2003; 85(1):73-81.

Xu YX, Kim KM, Hanna MA, Nag D. Chitosan-starch composite film: preparation and characterization. Industrial crops and Products. 2005; 21(2):185-92.

Zahedi Y, Ghanbarzadeh BA, Sedaghat N. Physical properties of edible emulsified films based on pistachio globulin protein and fatty acids. Journal of Food Engineering. 2010; 100(1):102-8.

\section{How to cite this article:}

Sharma D, Dhanjal DS, Mittal B. Development of Edible Biofilm Containing Cinnamon to Control Food-Borne Pathogen. J App Pharm Sci, 2017; 7 (01): 160-164. 